

\title{
Intraventricular ganglioglioma with unusual location and morphology-A case report
}

\author{
Shivakumar ${ }^{4}$ and Bhushan Chaudhary ${ }^{5}$ \\ hospital, Goa, India \\ ${ }^{2}$ Consultant radiologist, Apollo Hopsital Bangalore, India \\ ${ }^{3}$ Consultant neurosurgeon, Apollo Hopsital Bangalore, India \\ ${ }^{4}$ consultant pathologist, Apollo Hopsital Bangalore, India \\ ${ }^{5}$ DNB Resident, Apollo Hospital Bangalore, India
}

Mugdha Kamat Timble ${ }^{1 *}$, Aruna Patil ${ }^{2}$, Arun L Naik ${ }^{3}$, Swarna

${ }^{1}$ Former DNB Resident at Apollo Hospital Bangalore, Presently consultant radiologist in Manipal

Received: 04 December, 2019

Accepted: 05 February, 2020

Published: 06 February, 2020

*Corresponding author: Mugdha Kamat Timble, Former DNB Resident at Apollo Hospital Bangalore, Presently consultant radiologist in Manipal hospital, Shantadurga Housing Society, Deulwada, Marcela Goa403107, Goa, India,

E-mail: mugdhakamattimble@gmail.com

https://www.peertechz.com

Check for updates

\begin{abstract}
Ganglioglioma is one of the common tumour responsible for refractory temporal lobe epilepsy in children and young adults. Positioned in the group glioneural tumours, it is mostly of low grade histology. Here we outline a rare case of intraventricular ganglioglioma at atypical location with atypical morphology, lacking its most classical symptom of epilepsy.
\end{abstract}

\section{Introduction}

Tumour of young adults and children, ganglioglioma constitutes $1 \%$ of all brain malignancies [1]. It is described as one of the most common malignancy associated with temporal lobe epilepsy along with DNET [2]. However intraventricular counterpart of ganglioglioma is less likely to be associated with seizures and is more common in females [2]. Despite being neoplasm of low grade histology, it is likely to show progression into anaplastic variants, hence early diagnosis and surgical resection is of utmost importance.

\section{Case report}

10 year old female child presented with history of chronic gradual onset headache for 1year accompanied with occasional vomiting. There was progressive deterioration of vision for 1 year. No history of weakness in limbs or seizures was elicited.

MRI revealed well defined heterogeneously enhancing mass arising from the foramen of Munro (Figure 1). The mass was seen obstructing the 3rd ventricle causing bilateral lateral ventricular dilatation with periventricular ooze and corpus callosum thinning. The mass was hypointense to cortex on T1-weighted image (T1-WI) and intermediate signal intensity on T2-weighted image (T2-WI). Areas of blooming was seen within the mass on $\mathrm{T}_{2} *$-weighted image ( $\mathrm{T} 2 *-\mathrm{WI}$ ) along with cystic changes. The mass was seen compressing the hypothalamus inferiorly and supra-optic recess superiorly. Preoperative diagnosis of central neurocytoma or intraventricular ependymoma was suggested.

Patient underwent right frontal craniotomy and decompression of intraventricular tumour. Intraoperatively the tumour was highly vascular and was fed by the choroidal arteries with adherence to surrounding structures. To avoid injury to surrounding vital structures only decompression of tumour was performed.

On follow up CT (Figure 2a) residual heterogeneous mass with haemorrhagic areas was seen at the foramen of Munro level with persisting obstructive hydrocephalus. Right VP shunt 
was placed. Significant improvement in vision was recorded postoperatively.

Histopathology (Figure 2b) revealed tumour composed of neuronal and glia elements. The neuronal elements had dysplastic features with abnormal clustering and occasional binucleated and multinucleated cells. The ganglion cells were large having central to eccentric nuclei with abundant cytoplasm. Some of the cells had prominent nucleoli. The glial component showed dense fibrillary network and areas of cystic change. Few Rosenthal fibres and eosinophilic granular bodies were seen. There was mild vascular proliferation seen with perivascular cuffing of lymphocytes. Plenty of cyst macrophages along with chronic inflammatory cells composed
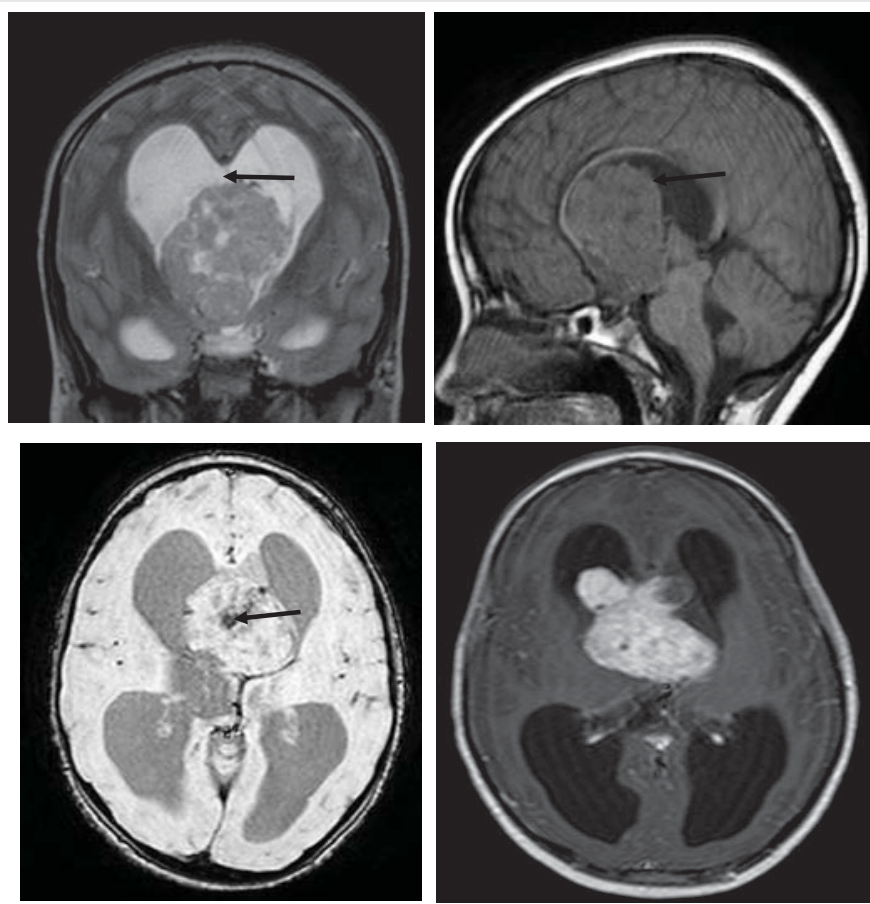

Figure 1: T2-WI coronal, T1-WI sagittal , T2*-WI , post contrast T1-WI with fat saturation axial images reveal mass arising from the foramen of munro level appearing intermediate signal with cystic spaces on T2- WI , hypointense on T1-WI areas of blooming seen on $\mathrm{T} 2{ }^{*}-\mathrm{WI}$, heterogenous enhancement on post contrast scan
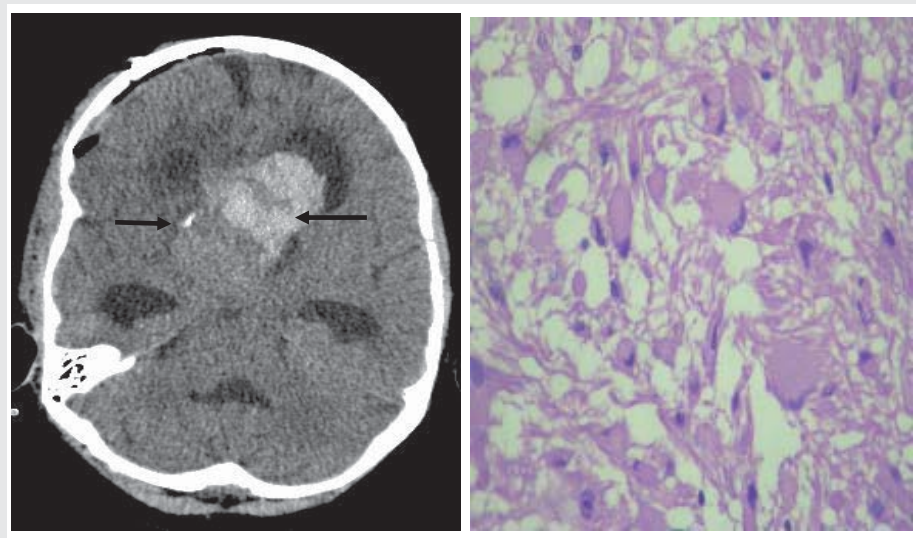

Figure 2: (a) Post operative CT reveal calcification and post operative bleed in mass with persistence of hydrocephalous.(b) Histopathology image revealing presence of ganglion and glial cells. of lymphocytes were also seen. Microcalcification was seen. The tumour showed marked capillary network resembling malformative angiomatous component. No mitosis or necrosis seen.

Immunohistochemistry (IHC) revealed positive results for GFAP, synaptophysin, NF ( indicates positive for ganglion cells), CD34 (indicates positive for endothelial cells) and Ki67 Labelling index were $<1 \%$. The final pathological diagnosis was Ganglioglioma.

No radio-chemotherapy was given as the tumour was of grade.

\section{Discussion}

Ganglioglioma is the most common neuronal-glial neoplasm of the CNS. Cyst with mural nodule has been described as its classical appearance $(52 \%)$ on cross sectional imaging with temporal lobe as the most favoured site (38\%40\%) [3]. However our patient lacked classical morphological appearance and site. Atypical appearances of ganglioglioma includes solid mass (43\%) and cystic mass (5\%). Atypical location of ganglioglioma include parietal lobe $(30 \%)$, frontal lobe $(18 \%)$, very rare location includes brainstem, cerebellum, spinal cord, pineal region, optic nerve optic chiasma and ventricles [4]. Tumor is most commonly seen in children and young adults [4].

On unenhanced CT $38 \%$ of ganglioglioma are hypodense, $32 \%$ have mixed attenuation, $15 \%$ Isodense, $15 \%$ hyperdense. Calcification is seen in $30 \%$ of cases. Approximately $16 \%-80 \%$ show enhancement on post contrast study. Ganglioglioma show variable MR features with most appearing hypointense to isointense to grey matter on $\mathrm{T} 1$ and hyperintense on $\mathrm{T} 2$. Rarely may they also appear hyperintense on $\mathrm{T} 1$. On T2 some areas of high signal are ideal for the diagnosis of ganglioglioma. On gadolinium enhanced images the lesion may show homogenous, ring like or no enhancement $[1,2]$.

Hauck, et al., [5] and Goncalves, et al., [1], described the predilection for female gender in cases of intraventricular ganglioglioma in comparison to its cortical counterpart, which is also seen in our case. To our knowledge, only 3 cases of intraventricular Ganglioglioma with haemorrhage have been described in literature [6]. Goncalves, et al., [1], also described bizarre (eccentric and exuberant) pattern of calcification in these tumours.

\section{Conclusion}

Ganglioglioma is predominant cortical tumour, and intraventricular location is rare. Atypical clinical features depicted in our case is lack of seizures which is most common symptom of cortical Ganglioglioma. Female preponderance of intraventricular location is also of divergent behaviour. Hence differential of Ganglioglioma should be considered in young female with intraventricular mass. 


\section{References}

1. Gonçalves V, Reis F, Bertanha R, Queiroz LS, Rogério F, et al. (2014) Intraventricular gangliogliomas: two case reports-two distinct patterns of intraventricular gangliogliomas 1: 651. Link: http://bit.ly/373SY3V

2. Englot DJ, Chang EF, Vecht CJ (2016) Epilepsy and brain tumors. Handb Clin Neurol 134: 267-285. Link: http://bit.ly/2vMqluX

3. Samdani AF, Torre-Healy A, Khalessi A, McGirt M, Jallo Gl, et al. (2009) Intraventricular ganglioglioma: a short illustrated review. Acta Neurochir 151 635-640. Link: http://bit.ly/20uu6M6
4. Shin JH, Lee HK, Khang SK, Kim DW, Jeong AK, et al. (2002) Neuronal tumors of the central nervous system: radiologic findings and pathologic correlation. Radiographics 22: 1177-1189. Link: http://bit.ly/31tEpp2

5. Hauck EF, Vu L, Campbell GA, Nauta HJ (2008) Intraventricular ganglioglioma J Clin Neurosci 15: 1291-1293. Link: http://bit.ly/397Tr6k

6. Warnica W, Provias JP (2017) Intraventricular ganglioglioma with extensive hemorrhage. Clin Neuropathol 36: 178-182. Link: http://bit.ly/2urpTCb

\section{Discover a bigger Impact and Visibility of your article publication with}

\section{Peertechz Publications}

\section{Highlights}

* Signatory publisher of ORCID

- Signatory Publisher of DORA (San Francisco Declaration on Research Assessment)

* Articles archived in worlds' renowned service providers such as Portico, CNKI, AGRIS, TDNet, Base (Bielefeld University Library), CrossRef, Scilit, J-Gate etc.

* Journals indexed in ICMJE, SHERPA/ROMEO, Google Scholar etc.

- OAI-PMH (Open Archives Initiative Protocol for Metadata Harvesting)

* Dedicated Editorial Board for every journal

* Accurate and rapid peer-review process

* Increased citations of published articles through promotions

* Reduced timeline for article publication

Submit your articles and experience a new surge in publication services (https://www.peertechz.com/submission).

Peertechz journals wishes everlasting success in your every endeavours.

Copyright: @ 2020 Timble MK, et al. This is an open-access article distributed under the terms of the Creative Commons Attribution License, which permits unrestricted use, distribution, and r eproduction in any medium, provided the original author and source are credited. 